\title{
Two new coastal species of Elaphropeza Macquart (Diptera: Hybotidae) from Bali, Indonesia
}

\author{
Patrick GROOTAERT ${ }^{1,3}$, Isabella VAN DE VELDE ${ }^{1,4}$ \& Igor V. SHAMSHEV ${ }^{1,2,5}$ \\ ${ }^{1}$ Entomology, Royal Belgian Institute of Natural Sciences, Vautierstraat 29, B-1000 Brussels, Belgium. \\ Email: Patrick.Grootaert@naturalsciences.be and Isa.VandeVelde@naturalsciences.be \\ ${ }^{2} Z$ oological Institute, Russian Academy of Sciences, Universitetskaja nab. 1, St. Petersburg 199034, \\ Russia.Email: shamshev@mail.ru \\ ${ }^{3}$ urn:Isid:zoobank.org:author:B80BC556-9087-4D0D-9D69-7FA9BE5779C4 \\ ${ }^{4}$ urn:lsid:zoobank.org:author:CB1B2335-553C-4A40-BB10-19C62E3875C6 \\ ${ }^{5}$ urn:Isid:zoobank.org:author:569F41CC-EC2B-4CF0-802A-8D7056C72C93
}

\begin{abstract}
Two new species of Elaphropeza Macquart, 1827 are described from the northeast coast of Bali (Indonesia): Elaphropeza triseta sp. nov. belonging to the ephippiata-group and E. balinensis sp. nov. belonging to the biuncinata-group. A COI Neighbour-Joining tree is given for the Southeast Asian Elaphropeza species showing large genetic distances between the species. The morphological characterisation of the ephippiata-group and the biuncinata-group sensu Shamshev \& Grootaert 2007 is confirmed.
\end{abstract}

Key words. Elaphropeza, new species, Hybotidae, Southeast Asia.

Grootaert P., Van de Velde I. \& Shamshev I. 2015. Two new coastal species of Elaphropeza Macquart (Diptera: Hybotidae) from Bali, Indonesia. European Journal of Taxonomy 112: 1-10. http://dx.doi.org/10.5852/ejt.2015.112

\section{Introduction}

Shamshev \& Grootaert (2007) revised the genus Elaphropeza in the Oriental Realm, reporting 79 species. Apart from the redescription of the holotypes of previously known species, 51 new species were described mainly from Singapore. These new species were the result of a one-year collecting campaign with Malaise traps in various biotopes in Singapore, e.g., swamp forest, secondary rain forest and mangrove. Later, three species were described from Vietnam by Grootaert \& Shamshev (2009). These species were remarkable in having brush-like clusters of long hairs in the intertergal spaces between tergites 3 and 4 and sometimes 4 and 5 as well. These brushes might help in the evaporation of pheromones secreted by the glands below the tergites.

Subsequently, Grootaert \& Shamshev (2012) published a monograph on the Tachydromiinae of Singapore which was partly based on a one-month site assessment study performed in 2009 , when insects were collected with Malaise traps in thirteen mangrove fragments all along the coast of Singapore. In that monograph another eight Elaphropeza species were described, all being coastal. Finally, Wang et al. (2012) described two new Elaphropeza species from Taiwan (Wang et al. 2012). Thus, 137 species of Elaphropeza are now known for the Oriental realm, including the two new species described in the 
present paper. This number is considered only a fraction of the number of species that might eventually be found to occur in the Oriental realm, since most species have only been recorded from the limited territory of Singapore with an emphasis on fauna restricted to mangroves.

At the end of 2013 the first two authors collected a small number of specimens of Elaphropeza from shrubs in the supralittoral zone of a shingle beach with black volcanic sands on the northeast coast of Bali. It is the first record of the genus in Bali and the specimens belong to two species that are new to science. They are described, illustrated, COI-barcoded and compared with the other species known from the Oriental realm in order to confirm the separation of the genus Elaphropeza in two species groups (Shamshev \& Grootaert 2007).

\title{
Material and methods
}

Specimens were collected by sweep netting and preserved in 70\% ethanol. Holotypes are conserved in the Museum Zoologici Bogor, Indonesia (MZB). The specimens from which DNA was extracted are conserved in the tissue collection at the Royal Belgian Institute of Natural Sciences, Brussels (RBINS), with the cuticular parts still being recognisable. For the barcoding technique we refer to Nagy et al. (2013). The evolutionary history was inferred using the Neighbor-Joining method MEGA6 (Tamura et al. 2013). The optimal tree with the sum of branch lengths $=1.87955927$ is shown. The percentages of replicate trees in which the associated taxa clustered together in the bootstrap test (1000 replicates) are shown next to the branches. The tree is drawn to scale, with branch lengths in the same units as those of the evolutionary distances used to infer the phylogenetic tree. The evolutionary distances were computed using the Maximum Composite Likelihood method and are in the units of the number of base substitutions per site. The analysis involved 39 nucleotide sequences. Codon positions included were $1^{\text {st }}+2^{\text {nd }}+3^{\text {rd }}+$ Noncoding. All positions containing gaps and missing data were eliminated. There was a total of 640 positions in the final dataset. Evolutionary analyses were conducted in MEGA6 (Tamura et al. 2013).

\section{Results}

\author{
Class Insecta Linnaeus, 1758 \\ Order Diptera Linnaeus, 1758 \\ Superfamily Empidoidea Latreille, 1804 \\ Family Hybotidae Macquart, 1823 \\ Subfamily Tachydromiinae Meigen, 1822
}

Elaphropeza Macquart, 1827

Elaphropeza Macquart, 1827: 86 (as genus). Type-species: Tachydromia ephippiata Fallén, 1815: 11, by monotypy.

Ctenodrapetis Bezzi, 1904: 351 (as subgenus of Drapetis). Type-species: Ctenodrapetis ciliatocosta Bezzi, 1904 by subsequent designation of Melander (1928: 309).

\author{
Elaphropeza triseta sp. nov. \\ urn:lsid:zoobank.org:act:CD141962-6947-4418-AB0B-25A25A2F41E7
}

Figs $1-4$

\section{Diagnosis}

A species of the E. ephippiata group; recognised by almost entirely yellow thorax, only postnotum brownish along posterior margin; antenna with scape and pedicel yellow; postpedicel short, about 1.5 times as long as wide, brown; legs yellow, with only tarsomere 5 dark brown, hind tibia with 3 brownish black anterodorsal bristles; halter yellow. 


\section{Etymology}

The specific epithet refers to the presence of three anterodorsal bristles on the hind tibia.

\section{Type material}

\section{Holotype}

INDONESIA: Ō, Bali, Amed, Bunutan, beach, 8²0’19.44” S, 115³9’53.39” E, 2 Jan. 2014, leg. P. Grootaert \& I. Van de Velde (MZB).

\section{Paratypes}

INDONESIA: $2 \hat{\jmath} \widehat{\partial}, 2$ 우, Bali, Amed, same provenance as holotype (RBINS); $2 \hat{\jmath} \hat{\jmath}, 2$ 우, Bali, Arya Amed, Bunutan, 8²0’38.89” S, 11540’21.81” E, 25 Dec. 2013, leg. P. Grootaert \& I. Van de Velde (RBINS).

\section{Description}

\section{Male (Fig. 1)}

LeNGTH. Body $2.3 \mathrm{~mm}$, wing $2.1 \mathrm{~mm}$.

HEAD. Occiput entirely black, largely shining, with yellowish setae; inner verticals long inclinate, outer verticals hardly prominent. Anterior ocellars long proclinate, posterior ocellars minute. Frons subshining, very narrow, above antennae about as broad as anterior ocellus. Antenna with scape and pedicel yellow, postpedicel and stylus brownish; pedicel with circlet of subequally short setulae; postpedicel short,

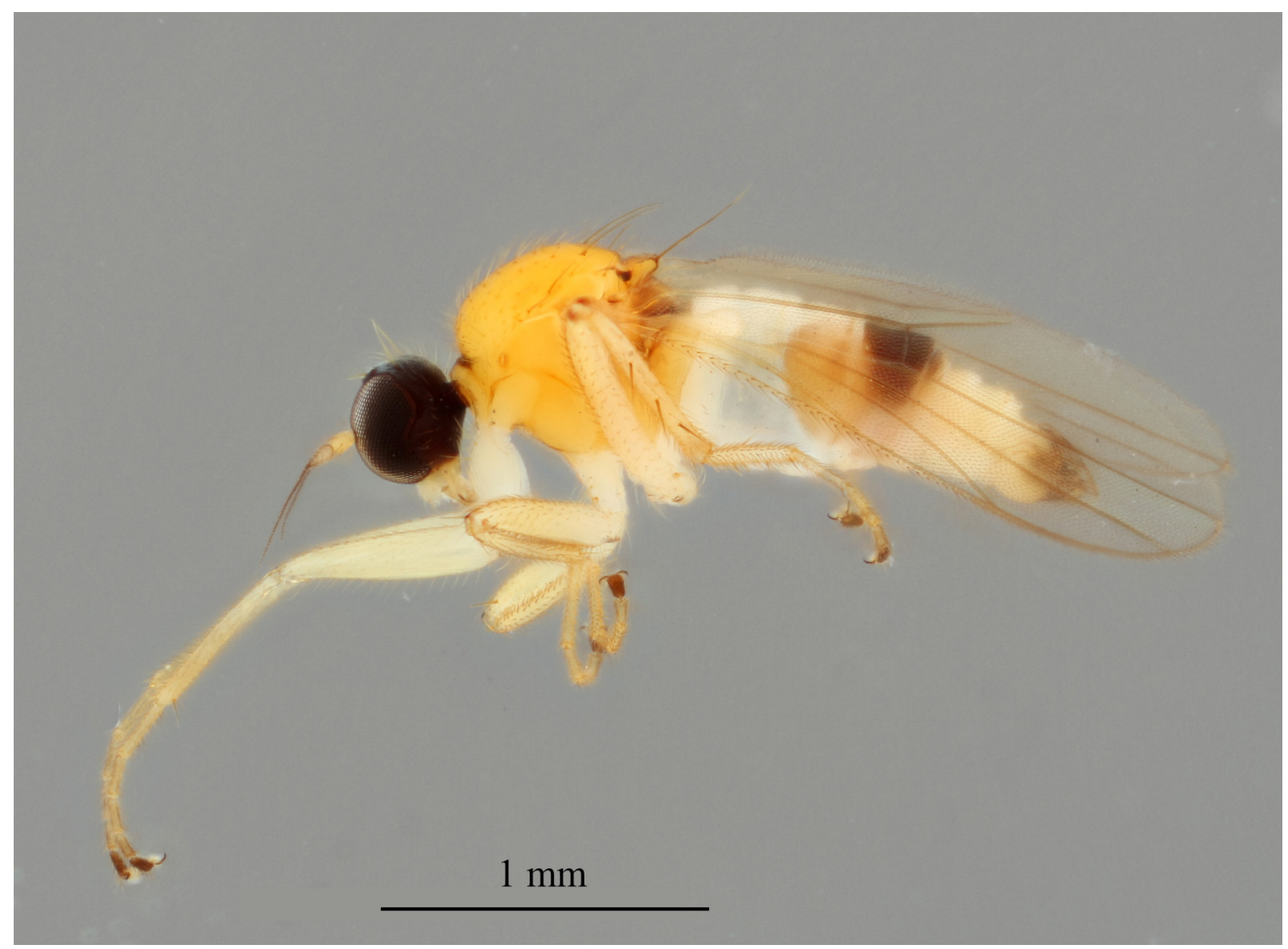

Fig. 1. Elaphropeza triseta sp. nov. Male habitus (photo J. Brecko). 
nearly 1.5 times as long as wide; stylus very long, nearly 4.0 times as long as postpedicel, with short pubescence. Proboscis brownish yellow. Palpus yellow, small, rounded, silvery pubescent, bearing scattered setulae, subapical seta short.

THORAX. Almost entirely yellow, only antepronotum with brownish spot dorsally, postnotum brownish along posterior margin, hypopleuron brownish on extreme apex and metapleuron yellowish brown on upper part anteriorly; shining, with yellowish setation; anterior spiracle brownish yellow, posterior spiracle brown. Prothoracic episterna lacking long upturned seta just above fore coxa, with minute setula on upper part. Postpronotal seta hardly prominent. Mesonotum with 2 long notopleurals, 1 shorter postsutural supra-alar, 1 long postalar and 4 scutellars (apical pair very long, cruciate; lateral pair short); acrostichals short, arranged in 4 irregular rows anteriorly but becoming sparser and biserial posteriorly, distinctly separated from dorsocentrals, lacking on prescutellar depression; dorsocentrals arranged in 3-4 irregular rows, as long as acrostichals, 1 prescutellar pair very long.

LEGS. Long, slender, almost entirely yellow, only tarsomere 5 of all legs dark brownish. Coxae and trochanters with unmodified setation. Fore femur slightly thickened, with rows of minute anteroventral and posteroventral setae, long seta near base and 1 subapical bristle anteriorly. Fore tibia lacking prominent bristles (except subapicals). Mid femur with rows of minute anteroventral and posteroventral spinule-like setae (more numerous near base), 1 long seta near base and 1 long subapical bristle anteriorly. Mid tibia only with 1 black, short, subapical spine, lacking prominent setae (except subapicals). Hind femur with short anteroventrals and 3 erect dorsal setae near base. Hind tibia with 3 brownish black anterodorsal bristles; apical projection small, rounded, brownish. Tarsi of all legs unmodified, with unmodified setation.
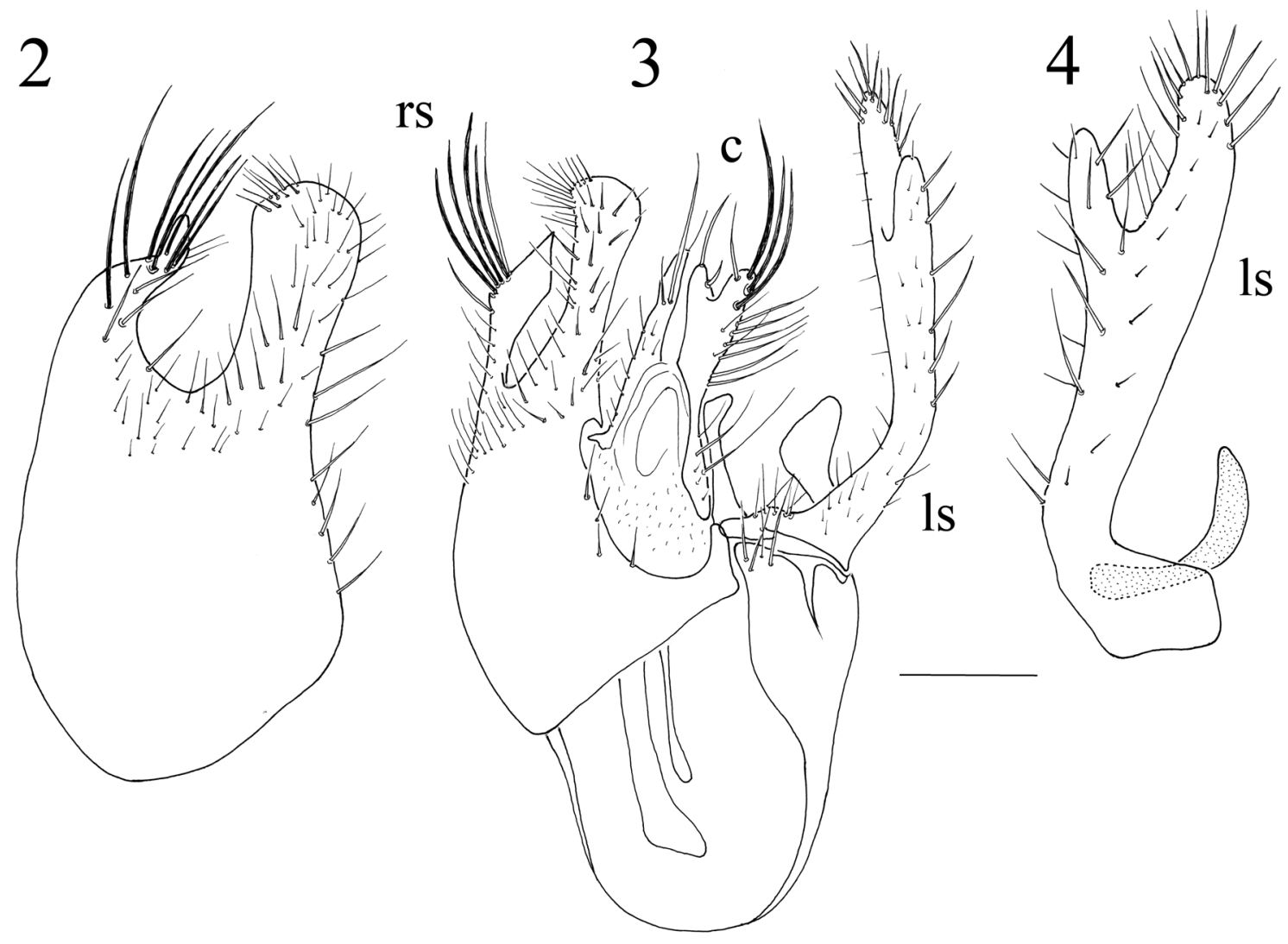

Figs 2-4. Elaphropeza triseta sp. nov. Male terminalia. 2. Right epandrial lamella. 3. Epandrium with cerci. 4 . Left surstylus. $\mathrm{c}=$ cerci; $1 \mathrm{~s}=$ left surstylus; $\mathrm{rs}=$ right surstylus. Scale bar $=0.1 \mathrm{~mm}$. 
WINGS. Normally developed, finely infuscate, covered with uniform microtrichia; veins mostly yellowish brown; basal section of $\mathrm{M}_{1+2}$, crossveins bm-cu and r-m pale. Costal vein with moderately long, uniform setulae along anterior margin. Costal bristle long, brown. Costal index: 41/31/31. Vein Rs long, slightly longer than crossvein bm-cu. Vein $\mathrm{R}_{2+3}$ evenly bowed. Veins $\mathrm{R}_{4+5}$ and $\mathrm{M}_{1+2}$ somewhat divergent near wing apex, $\mathrm{R}_{4+5}$ slightly bowed, $\mathrm{M}_{1+2}$ straight. Vein $\mathrm{CuA}_{1}$ reaching wing margin. Vein $\mathrm{A}_{1}$ lacking. Crossvein $\mathrm{bm}$-cu slightly oblique. Crossvein r-m before middle of cell bm. Squama yellowish, with long, brownish yellow setae. Halter yellow.

AвDomen. Tergite 1 pale yellow; tergites $2-3$ brownish yellow, subtriangular viewed laterally, divided medially, with scattered unmodified setae; tergite 4 brown, broadest, with squamiform setae; tergite 5 narrow, undivided, with squamiform setae; an ampoule-like structure below tergite 5; tergites 6-7 brownish yellow, tergite 6 undivided, with minute unmodified setae; tergite 7 undivided, with long posteromarginal setae; tergite 8 unmodified. Sternites yellowish, with scattered minute setae, sternite 8 with long, posteromarginal setae. Gland-like structure present between tergites 4 and 5, ampoule-like. Terminalia (Figs 2-4) rather small, with cerci, apical part of right epandrial lamella and left surstylus brownish, otherwise yellow. Right epandrial lamella bifid (Fig. 2); dorsal lobe with setae on dorsal margin. Tip with a brush of densely set, short setae. Ventral lobe with strong brown setae on apex. Right and left cerci equally long. Right cercus with a single long subapical seta, other setae short. Left cercus (Fig. 3) bifid; outward lobe with 3 strong brown setae on apex. Tip of left epandrial lamella with 4 setae: 1 weak and 3 stronger. Left surstylus also bifid, with short setae (Fig. 4).

\section{Female}

Similar to male; abdomen without ampoule-like gland-like structure; intersegmental area between tergites 4 and 5 set with short hairs, anteriorly with 2 openings; segment 8 moderately long, tergite and sternite 8 separated, yellowish brown; tergite 8 entire, with several short to moderately long setae posteriorly; sternite 8 entire, covered with moderately long setae; cercus small, yellowish.

\section{Distribution}

Bali, Indonesia.

\section{Remarks}

Elaphropeza triseta sp. nov. is actually the only yellow Oriental species with three anterodorsal setae on the hind tibiae. In the key of Grootaert \& Shamshev (2012), E. triseta sp. nov. resolves closest to E. acrodactyla (Melander, 1928), described from a female from the Philippines, but the latter has only two anterodorsal bristles on the hind tibiae and has the postpedicel about three times as long as wide. In $E$. triseta sp. nov. the postpedicel is nearly 1.5 times as long as wide.

\section{Elaphropeza balinensis sp. nov. urn:Isid:zoobank.org:act:D744E850-5F65-4C29-A671-9F9D0872A6A9}

Figs $5-10$

\section{Diagnosis}

A species of the E. biuncinata group; thorax yellow, scutum with narrow, short, brownish patch above wing; antenna with short postpedicel, about 2.0 times as long as wide; legs yellow, but all tibiae and tarsi faintly brownish tinged, including apical tarsomere of all legs; hind tibia with 1 short, black anterodorsal bristle at about middle and 1 similar subapical bristle anteriorly; halter brownish. Scutum entirely covered with setae (acrostichals and dorsocentrals not differentiated), reaching base of scutellum. 


\section{Etymology}

The specific epithet refers to the provenance from Bali.

\section{Type material}

\section{Holotype}

INDONESIA: О̊, Bali, Amed, Bunutan, beach, Arya Amed, 8²0’38.89” S, 11540’21.81” E, 2 Jan. 2014, leg. P. Grootaert \& I. Van de Velde (MZB).

\section{Paratypes}

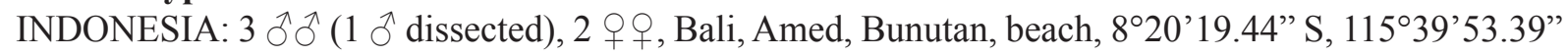
E, 26 Dec. 2013, leg. P. Grootaert \& I. Van de Velde (RBINS).

\section{Description \\ Male (Fig. 5) \\ LeNGTH. Body $1.8 \mathrm{~mm}$, wing $1.6 \mathrm{~mm}$.}

HEAD. Occiput entirely black, largely shining, with yellowish setae; inner verticals long inclinate, outer verticals short. Anterior ocellars long proclinate, posterior ocellars minute. Frons subshining, very narrow, above antennae about as broad as anterior ocellus. Antenna with scape and pedicel yellow, postpedicel and stylus brownish; pedicel with circlet of subequally short setulae; postpedicel short, nearly 2 times as long as wide; stylus with short pubescence, very long, 2.5-3.0 times as long as postpedicel. Proboscis brownish yellow. Palpus yellow, small, rounded, bearing scattered setulae, subapical seta short.

Thorax. Almost entirely yellow, scutum with narrow, short, brownish yellow patch above wing on each side (indistinct in paler specimens), metanotum slightly shadowed on middle part (sometimes only posteriorly or entirely yellow), mesopleuron posteriorly and sternopleuron on lower part usually with small, brownish yellow patch; shining, with yellowish setation; spiracles brownish yellow. Prothoracic episterna with long, upturned seta just above fore coxa. Postpronotal seta not prominent. Mesonotum with 2 long notopleurals, 1 short postsutural supra-alar, 1 moderately long postalar and 4 scutellars (apical pair long, cruciate; lateral pair short); scutum covered with uniform, minute setae, extending to base of scutellum. Acrostichals and dorsocentrals not differentiated, except for 1 pair of long, prescutellar dorsocentrals.

Legs. Robust, yellow, but all tibiae and tarsi yellowish-brownish tinged. Coxae and trochanters with unmodified setation. Fore femur slightly thickened, with rows of minute anteroventral and posteroventral setae, long seta near base and 1 subapical bristle anteriorly. Fore tibia lacking prominent bristles (except subapicals). Mid femur with rows of minute anteroventral and somewhat longer posteroventral setae, 1 long seta near base and 1 moderately long subapical bristle anteriorly. Mid tibia with row of black, short, anteroventral spines on apical $3 / 4$, lacking prominent setae (except subapicals). Hind femur with minute anteroventrals and 3 erect, dorsal setae near base. Hind tibia with 1 short, black anterodorsal bristle on about middle and 1 similar subapical bristle anteriorly. Tarsi of all legs unmodified, with unmodified setation.

WINGS. Normally developed, finely infuscate, covered with uniform microtrichia; veins mostly yellowish brown; basal section of $\mathrm{M}_{1+2}$, crossveins bm-cu and r-m pale. Costal vein with moderately long, uniform setulae along anterior margin. Costal bristle moderately long, brown. Costal index: 29/22/26. Vein Rs long, nearly as long as crossvein bm-cu. Vein $\mathrm{R}_{2+3}$ evenly bowed. Veins $\mathrm{R}_{4+5}$ and $\mathrm{M}_{1+2}$ somewhat divergent near wing apex, both slightly bowed. Vein $\mathrm{CuA}_{1}$ reaching wing margin. Vein $\mathrm{A}_{1}$ lacking. Crossvein bm-cu oblique. Crossvein $\mathrm{r}-\mathrm{m}$ near middle of cell $\mathrm{bm}$. Squama yellowish brown, with long, brownish setae. Halter brownish. 
ABDOMEN. Tergite 1 largely pale yellow, very narrow, divided medially; tergite 2 broadly concave medially, undivided; tergite 3 broadest, subrectangular, with squamiform setae; tergites 4-5 narrow, both with squamiform setae; tergites 6-7 broader than tergite 5, the latter with moderately long, posteromarginal setae; sternites 3-4 broadly divided, sternite 5 entire, concave anteriorly, sternites 6-7 entire, subrectangular, with scattered minute setae. Gland-like structure present between tergites 3-4 and 4-5, plate-like. Terminalia (Figs 6-10) rather small; epandrium brown, otherwise yellow. Right epandrial lamella (Fig. 6) with base brown, apex (surstylus) yellowish; basal half of dorsal margin with 4 long, strong setae. Left epandrial lamella without the usual set of setae dorsally. Left surstylus composed

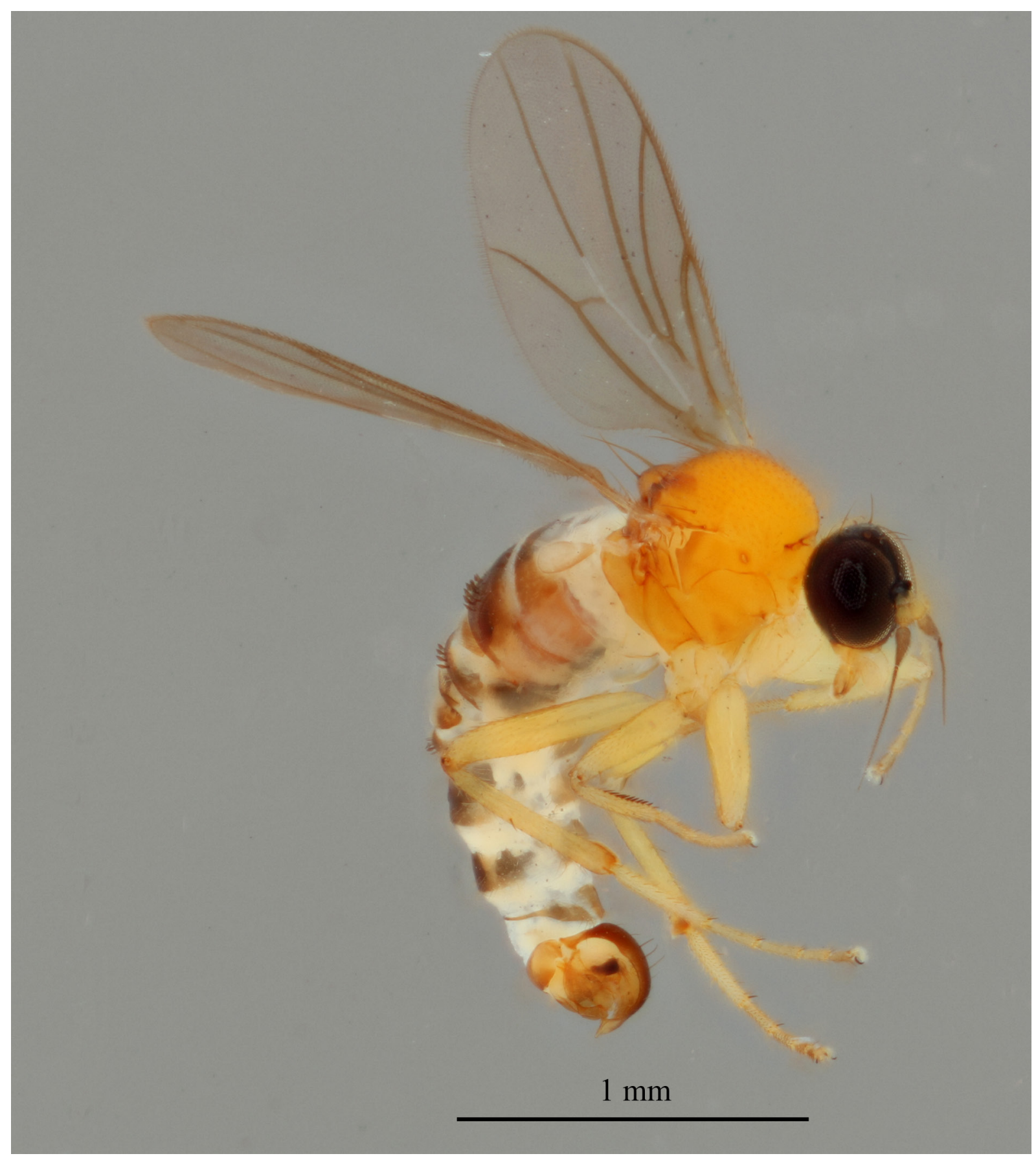

Fig. 5. Elaphropeza balinensis sp. nov. Male habitus (photo J. Brecko). 
of 3 pieces (Fig. 10), hidden by the large left cercus: 1s1 with apex indented (Fig. 9), on inner side with at least 6 setae; 1s 2 with apex saw-toothed; ls3 with short setae (Fig. 10). Phallus long, with partly coiled tip (Fig. 8). Right cercus short, with rather long setae. Left cercus very wide, covering the left surstylus; with only minute setae.

\section{Female}

Similar to male but mid tibia without anteroventral spines; abdominal tergites 3-7 of subequal width; segment 8 short, tergite 8 separated from sternite 8 , deeply cleft posteriorly; cercus short, yellowish.

\section{Distribution}

Bali, Indonesia.

\section{Remarks}

In the key of Grootaert \& Shamshev (2012), E. balinensis sp. nov. resolves closest to E. monospina Shamshev \& Grootaert, 2007, known only from Singapore. The latter also has a somewhat maculated scutum, but it has the hind tarsomere 1 with a spine-like ventral seta near the base. The structure of the male genitalia is also very different.

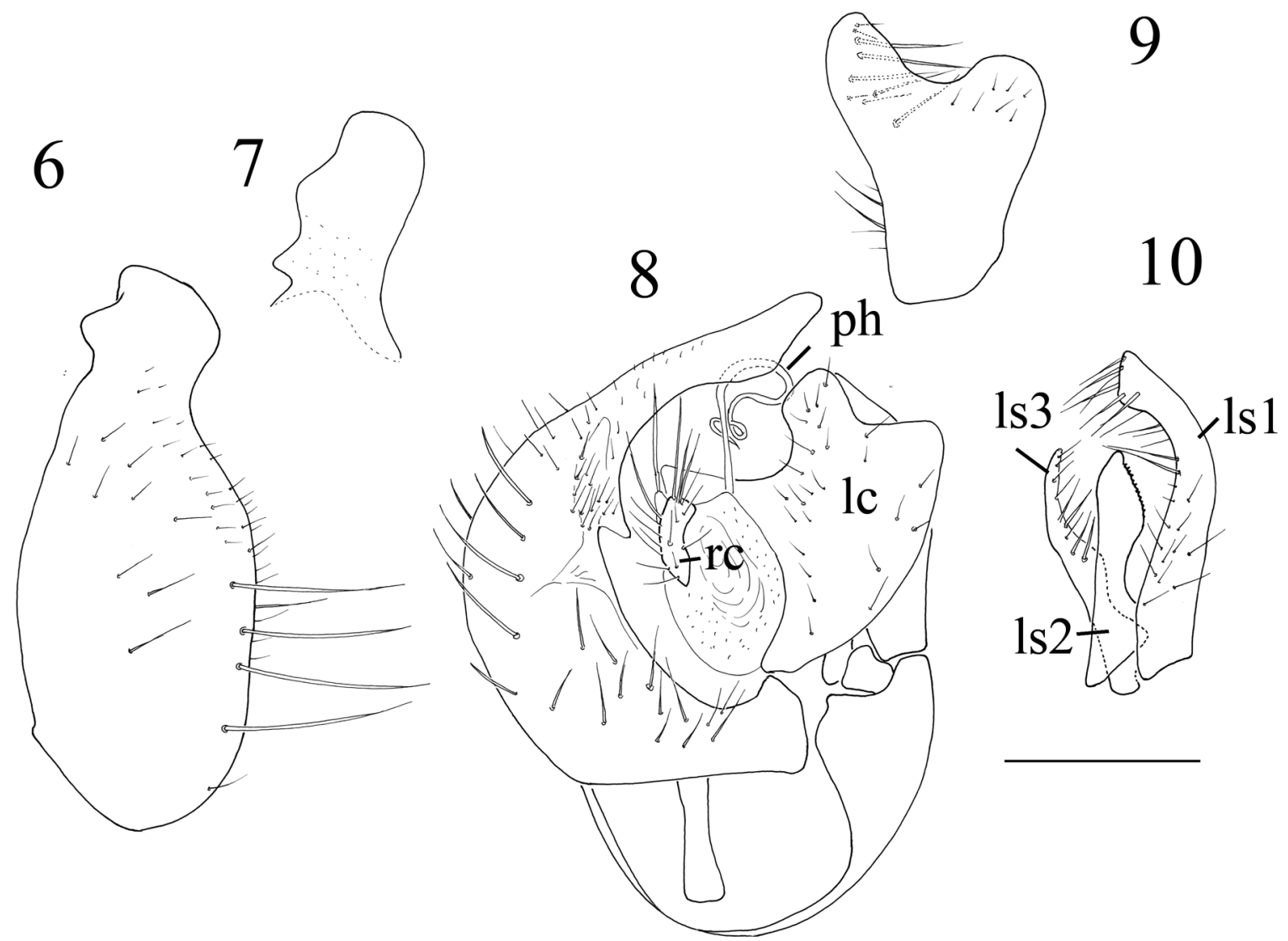

Figs 6-10. Elaphropeza balinensis sp. nov. Male terminalia. 6. Right epandrial lamella. 7. Detail of right surstylus. 8. Epandrium with cerci. 9. Left surstylus, 1s1. 10. Left surstylus. 1c = left cercus; 1s1, 1s2, 1s3 $=3$ sclerites of the left surstylus; $\mathrm{ph}=$ phallus; $\mathrm{rc}=$ right cercus. Scale bar $=0.1 \mathrm{~mm}$. 


\section{Discussion}

Shamshev \& Grootaert (2007) proposed two species groups in the Oriental Elaphropeza based on morphological characters. In species of the E. biuncinata group a long upturned bristle is present just above the fore coxa and the abdominal tergites 3, 4 and 5 bear squamiform setae (Fig. 5). In species of the E. ephippiata group the proepisternum is bare just above the fore coxa and the abdominal tergite 3 is covered with ordinary setulae, lacking squamiform setae, which are present on tergites 4 and/or 5 only. In addition, there are several characters in the male genitalia, such as fusion or not of the right surstylus with the right epandrial lamella, fusion or not of both cerci, short or very long phallus and more (Shamshev \& Grootaert 2007). This preliminary and informal classification is confirmed here by the COI gene (Fig. 11), with a bootstrap value of 86 for the biuncinata-group. However, it would not be practical to elevate the two species groups to genus level since the morphological characters are not always easy to see.

As can be seen further on Fig. 11, the genetic distance between all species is large and always more than $5 \%$, showing that at least for the selected species from the Oriental realm, this separation is already of considerable age.

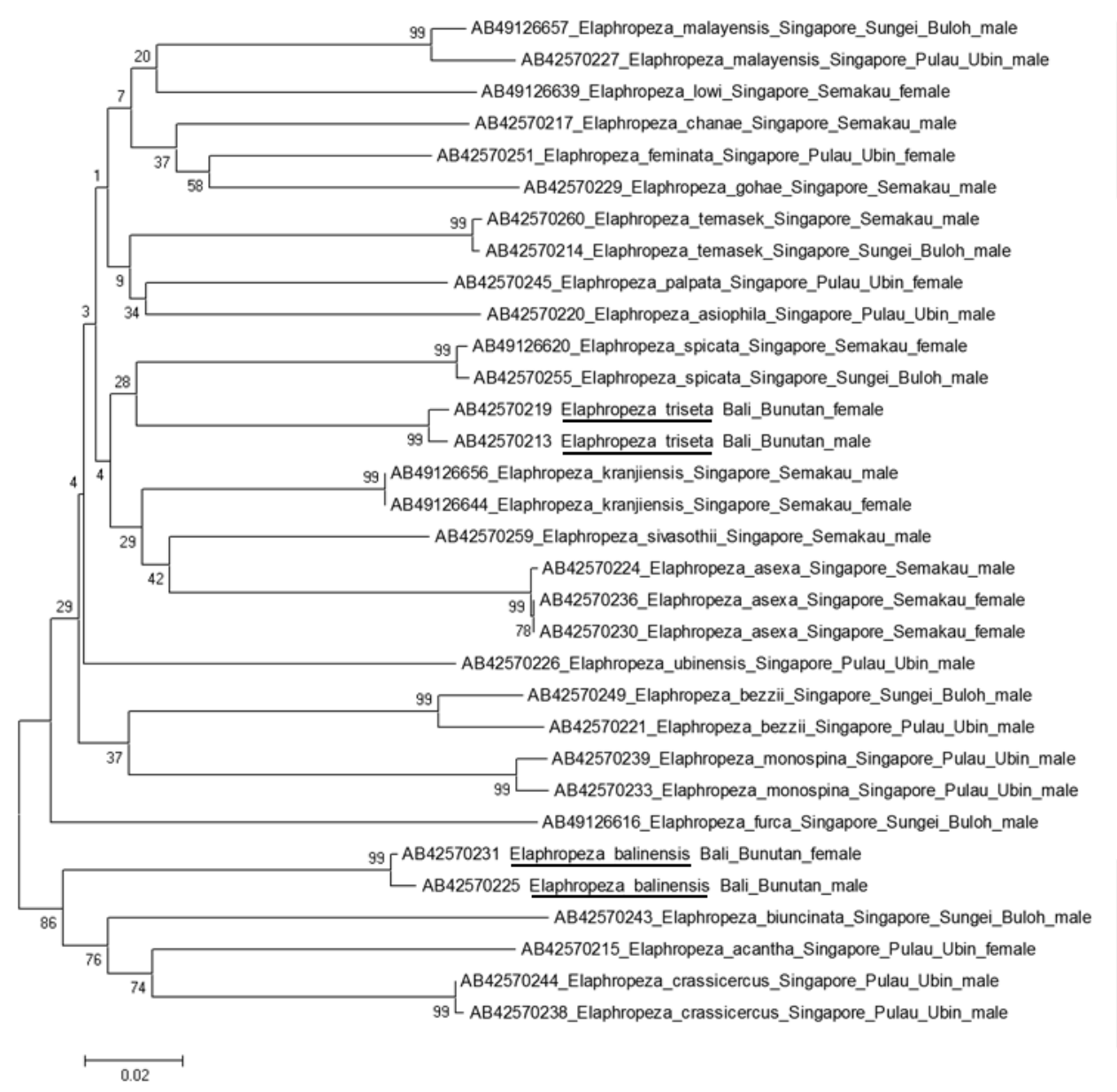

ephippiata

group

biuncinata

group

Fig. 11. Neighbour-Joining tree of the COI barcodes of a number of selected Southeast Asian Elaphropeza species showing the position of E. triseta sp. nov. and E. balinensis sp. nov. (both underlined) in the ephippiata-group and biuncinata-group, respectively. The bootstrap value is indicated at the nodes. The scale of the genetic distance is $2 \%$. 


\section{Acknowledgements}

The authors thank Mr Johan De Gruyter for the barcoding of the species. Mr Jonathan Brecko helped with the photography.

\section{References}

Bezzi M. 1904. Empididae Indo-australiani raccolti dal Signor L. Biro. Annales Historico-Naturales Musei Nationalis Hungarici 2: 320-361.

Fallén C.F. 1815. Empididae Sveciae. Berlingianus, Lund.

Grootaert P. \& Shamshev I.V. 2009. New species of the genus Elaphropeza Macquart (Diptera: Hybotidae) with remarkable abdominal structures from Viet Nam. Studia Dipterologica 15: 165-174.

Grootaert P. \& Shamshev I.V. 2012. The fast-running flies (Diptera, Hybotidae, Tachydromiinae) of Singapore and adjacent regions. European Journal of Taxonomy 5: 1-162. http://dx.doi.org/10.5852/ ejt.2012.5

Macquart J. 1827. Insectes Diptères du Nord de la France. Platypezines, Dolichopodes, Empides, Hybotides. L. Danel, Lille.

Melander A.L. 1928. Diptera, Fam. Empididae. In: Wytsman P. (ed.) Genera Insectorum 185: 1-434. http://www.biodiversitylibrary.org/item/60119\#page/315/mode/1up

Nagy Z., Sonet G., Mortelmans J., Vandewynkel C. \& Grootaert P. 2013. Using DNA barcodes for diversity assessment in Hybotidae (Diptera, Empidoidea). ZooKeys 365: 263-278. http://dx.doi. org/10.3897/zookeys.365.6070

Shamshev I.V. \& Grootaert P. 2007. Revision of the genus Elaphropeza Macquart (Diptera: Hybotidae) from the Oriental Region, with a special attention to the fauna of Singapore. Zootaxa 1488: 1-164.

Tamura K., Stecher G., Peterson D., Filipski A. \& Kumar S. 2013. MEGA6: Molecular Evolutionary Genetics Analysis version 6.0. Molecular Biology and Evolution 30: 2725-2729. http://dx.doi. org $/ 10.1093 / \mathrm{molbev} / \mathrm{mst} 197$

Wang J., Zhang L. \& Yang D. 2012. Two new species and one newly recorded species of Elaphropeza Macquart from Taiwan (Diptera, Empididae, Tachydromiinae). Zookeys 203: 15-25. http://dx.doi. org/10.3897/zookeys.203.3284

Manuscript received: 22 October 2014

Manuscript accepted: 10 December 2014

Published on: 13 February 2015

Topic editor: Koen Martens

Desk editor: Danny Eibye-Jacobsen

Printed versions of all papers are also deposited in the libraries of the institutes that are members of the EJT consortium: Muséum National d'Histoire Naturelle, Paris, France; National Botanic Garden of Belgium, Meise, Belgium; Royal Museum for Central Africa, Tervuren, Belgium; National History Museum, London, United Kingdom; Royal Belgian Institute of Natural Sciences, Brussels, Belgium; Natural History Museum of Denmark, Copenhagen, Denmark. 